\title{
Effect of water on the fluorine and chlorine partitioning behavior between olivine and silicate melt
}

\author{
Bastian Joachim $^{1,2}\left(\mathbb{D} \cdot\right.$ André Stechern $^{3}$ - Thomas Ludwig ${ }^{4}$ Jürgen Konzett ${ }^{1}$. \\ Alison Pawley ${ }^{5}$ Lorraine Ruzié-Hamilton ${ }^{5}$ - Patricia L. Clay ${ }^{5}$ - Ray Burgess ${ }^{5}$. \\ Christopher J. Ballentine ${ }^{2}$
}

Received: 14 September 2016 / Accepted: 16 January 2017

(C) The Author(s) 2017. This article is an open access publication

\begin{abstract}
Halogens show a range from moderate $(\mathrm{F})$ to highly $(\mathrm{Cl}, \mathrm{Br}, \mathrm{I})$ volatile and incompatible behavior, which makes them excellent tracers for volatile transport processes in the Earth's mantle. Experimentally determined fluorine and chlorine partitioning data between mantle minerals and silicate melt enable us to estimate Mid Ocean Ridge Basalt (MORB) and Ocean Island Basalt (OIB) source region concentrations for these elements. This study investigates the effect of varying small amounts of water on the fluorine and chlorine partitioning behavior at $1280^{\circ} \mathrm{C}$ and $0.3 \mathrm{GPa}$ between olivine and silicate melt in the Fe-free CMAS+F$\mathrm{Cl}-\mathrm{Br}-\mathrm{I}-\mathrm{H}_{2} \mathrm{O}$ model system. Results show that, within the uncertainty of the analyses, water has no effect on the chlorine partitioning behavior for bulk water contents ranging from $0.03(2) \mathrm{wt} \% \mathrm{H}_{2} \mathrm{O}\left(\mathrm{D}_{\mathrm{Cl}}^{\mathrm{ol} / \mathrm{melt}}=1.6 \pm 0.9 \times 10^{-4}\right)$ to 0.33 (6) $\mathrm{wt} \% \mathrm{H}_{2} \mathrm{O}\left(\mathrm{D}_{\mathrm{Cl}}^{\text {ol} / \mathrm{melt}}=2.2 \pm 1.1 \times 10^{-4}\right)$. Consequently, with the effect of pressure being negligible in the uppermost mantle (Joachim et al. Chem Geol 416:65-78, 2015), temperature is the only parameter that needs to be considered for the determination of chlorine
\end{abstract}

Communicated by Jochen Hoefs.

Bastian Joachim

bastian.joachim@uibk.ac.at

1 Institute for Mineralogy and Petrography, University of Innsbruck, Innrain 52, 6020 Innsbruck, Austria

2 Department of Earth Sciences, University of Oxford, South Parks Road, Oxford OX1 3 AN, United Kingdom

3 Institute for Mineralogy, Leibniz University of Hannover, Callinstrasse 3, 30167 Hannover, Germany

4 Institute of Earth Sciences, Heidelberg University, In Neuenheimer Feld 234-236, 69120 Heidelberg, Germany

5 School of Earth and Environmental Sciences, The University of Manchester, Manchester M13 9PL, United Kingdom partition coefficients between olivine and melt at least in the simplified iron-free $\mathrm{CMAS}+\mathrm{F}-\mathrm{Cl}-\mathrm{Br}-\mathrm{I}-\mathrm{H}_{2} \mathrm{O}$ system. In contrast, the fluorine partition coefficient increases linearly in this range and may be described at $1280^{\circ} \mathrm{C}$ and $0.3 \mathrm{GPa}$ with $\left(R^{2}=0.99\right): D_{F}^{\mathrm{ol} / \mathrm{melt}}=3.6 \pm 0.4 \times$ $10^{-3} \times X_{\mathrm{H}_{2} \mathrm{O}}(\mathrm{wt} \%)+6 \pm 0.4 \times 10^{-4}$. The observed fluorine partitioning behavior supports the theory suggested by Crépisson et al. (Earth Planet Sci Lett 390:287-295, 2014) that fluorine and water are incorporated as clumped $\mathrm{OH} / \mathrm{F}$ defects in the olivine structure. Results of this study further suggest that fluorine concentration estimates in OIB source regions are at least $10 \%$ lower than previously expected (Joachim et al. Chem Geol 416:65-78, 2015), implying that consideration of the effect of water on the fluorine partitioning behavior between Earth's mantle minerals and silicate melt is vital for a correct estimation of fluorine abundances in OIB source regions. Estimates for MORB source fluorine concentrations as well as chlorine abundances in both mantle source regions are within uncertainty not affected by the presence of water.

Keywords Fluorine $\cdot$ Chlorine $\cdot$ Halogen $\cdot$ Partitioning Water $\cdot \mathrm{H} 2 \mathrm{O} \cdot$ Earth's mantle $\cdot$ Mid Ocean Ridge Basalt $(\mathrm{MORB}) \cdot$ Ocean Island Basalt (OIB) · Olivine $\cdot$ Forsterite SIMS

\section{Introduction}

Owing to their incompatibility and volatility, the distribution of $\mathrm{H}_{2} \mathrm{O}$ and halogens in the Earth's mantle is influenced by processes such as fluid mobility, oxygen fugacity, fractionation, degassing, and partial melting. With quantification of their distribution between different mantle phases, this makes halogens excellent tracers of volatile transport 
processes (e.g., Schilling et al. 1980; Ito et al. 1983; Jambon et al. 1995). The volatile budget of the mantle profoundly affects, for instance, its viscosity, and therefore, the mode of mantle convection (e.g., Steinbach and Yuen 1995) responsible for heat transport and planetary cooling, implying that knowledge of the Earth's mantle volatile distribution will provide insight into the history and evolution of our planet. The determination of halogen abundances in Mid Ocean Ridge Basalt (MORB) and Ocean Island Basalt (OIB) source regions allows us to quantify volatile concentrations in their respective source regions (e.g., Beyer et al. 2012; Joachim et al. 2015). Comparing OIB source halogen concentrations with primitive mantle estimates enables us to better understand and quantify any volatile transport processes during recycling of oceanic crust.

For a long time, the only available approach to estimate bulk halogen concentrations, such as fluorine and chlorine, in MORB and OIB mantle source region was based on the analysis of element ratios, such as F/P, F/Sr and F/ $\mathrm{Nd}$, or $\mathrm{Cl} / \mathrm{K}$ and $\mathrm{Cl} / \mathrm{Nb}$ obtained from natural samples that were used as a proxy (Schilling et al. 1980; Ito et al. 1983; Michael and Schilling 1989; Déruelle 1992; Jambon et al. 1995; McDonough and Sun 1995; Newsom 1995; Wedepohl 1995; Saal et al. 2002; Salters and Stracke 2004; Le Roux et al. 2006; Workman et al. 2006; Shaw et al. 2008; Pyle and Mather 2009; Palme and O'Neill 2014). MORB and OIB source region estimates show, to date, a significant uncertainty. For example, fluorine OIB source region concentration estimates range from 8 ppm (Beyer et al. 2012) to $55 \mathrm{ppm}$ (Kovalenko et al. 2006), which covers a range from depleted to enriched abundances relative to primitive mantle estimates.

An independent approach is the experimental simulation of partial melting processes at the respective Earth's mantle source region conditions. By combining experimentally determined partition coefficients with natural halogen concentrations in oceanic basalts, halogen source region concentrations can be estimated. Recent experimental studies determined fluorine and chlorine partitioning data at pressure and temperature $(\mathrm{P}-\mathrm{T})$ conditions relevant for MORB and OIB source mantle regions between olivine, pyroxene, and corresponding silicate melt (Hauri et al. 2006; O'Leary et al. 2010; Beyer et al. 2012, 2016; Dalou et al. 2012; Joachim et al. 2015; Rosenthal et al. 2015). Joachim et al. (2015) showed that fluorine partitioning into olivine increases at nominally dry conditions by about two orders of magnitude between 1350 and $1600^{\circ} \mathrm{C}$ at pressures ranging from 1 to $2.3 \mathrm{GPa}$. The effect of pressure on fluorine partitioning between olivine and melt is negligible at least for pressures ranging between 1 bar-2.5 GPa (e.g., Beyer et al. 2012; Joachim et al. 2015). Fluorine partitioning data between olivine and silicate melt were determined by Hauri et al. (2006) and Dalou et al. (2014) with melt $\mathrm{H}_{2} \mathrm{O}$ contents of $1.7-25 \mathrm{wt} \%$ and in the $\mathrm{P}-\mathrm{T}$ range $1185-1245^{\circ} \mathrm{C}$ and $1-4$ GPa. Their data plot approximately $0.5-1$ orders of magnitude above the trend shown in Joachim et al. (2015) and are roughly in agreement with partition coefficients determined at higher temperatures ranging from 1345 to $1400^{\circ} \mathrm{C}$ and pressures ranging from 1 bar to $2.5 \mathrm{GPa}$ in nominally dry CMAS+F and NCMAS+F systems (Beyer et al. 2012). A potential explanation for the different fluorine partitioning behavior in hydrous and nominally anhydrous systems is the presence of water, which may lead to an increase of fluorine partitioning into olivine.

Chlorine partitioning between olivine and silicate melt is hardly investigated experimentally. Joachim et al. (2015) showed that chlorine partition coefficients between olivine and silicate melt in a nominally dry CMAS+F-Cl-Br-Isystem increases by approximately 1.5 orders of magnitude between 1350 and $1600^{\circ} \mathrm{C}$ at pressures ranging from 1.0 to $2.3 \mathrm{GPa}$. This increase is approximately comparable to the temperature effect on the fluorine partitioning behavior in the same temperature range. One data point provided by Dalou et al. (2014) from an experiment performed at $1240^{\circ} \mathrm{C}$ and $1.2 \mathrm{GPa}$ in the presence of a melt water content of $2.6 \mathrm{wt} \%$ plots about one order of magnitude above the trend shown in Joachim et al. (2015). This may indicate that the presence of water affects the chlorine partitioning behavior between olivine and melt.

To the best of our knowledge, no study have been available so far investigating the effect of variable bulk water contents on the fluorine and chlorine partitioning behavior between olivine and melt at a constant temperature.

Halogens may be incorporated into the olivine structure as point or planar defects. One type of planar defects known are humite-type lamellae (Kitamura et al. 1987; Drury et al. 1991; Risold et al. 2001; Stalder and Ulmer 2001; Wirth et al. 2001; Hermann et al. 2007). Transmission electron microscope (TEM) investigations give no indication for their presence at MORB or OIB source $\mathrm{P}-\mathrm{T}$ conditions (Beyer et al. 2012; Joachim et al. 2015). This has led to the conjecture that fluorine and chlorine are incorporated as point defects in the olivine lattice at Earth's mantle conditions. Potential mechanism may involve $\left[\mathrm{MgO}_{2}\right]^{2-}=$ $\left[\mathrm{F}_{2}\right]^{2-}$ as suggested by Bernini et al. (2013), or the replacement of a $\left[\mathrm{SiO}_{4}\right]^{4-}$ tetrahedron by a $\left[\mathrm{F}_{4}\right]^{4-}$ quadruplet (Crépisson et al. 2014) as proposed for fluorine incorporation in calcic and magnesian garnets (Valley et al. 1983; Smyth et al. 1990; Visser 1993).

Recent halogen mantle source region estimates indicate that the MORB source region is degassed by $22-88 \%$ in fluorine and $22-99 \%$ in chlorine relative to the primitive mantle (Joachim et al. 2015). The OIB source region, on the other hand, has a chlorine content similar to that of the primitive mantle, but is enriched in fluorine by a factor of 1.4-4.2 relative to the primitive mantle (Joachim et al. 


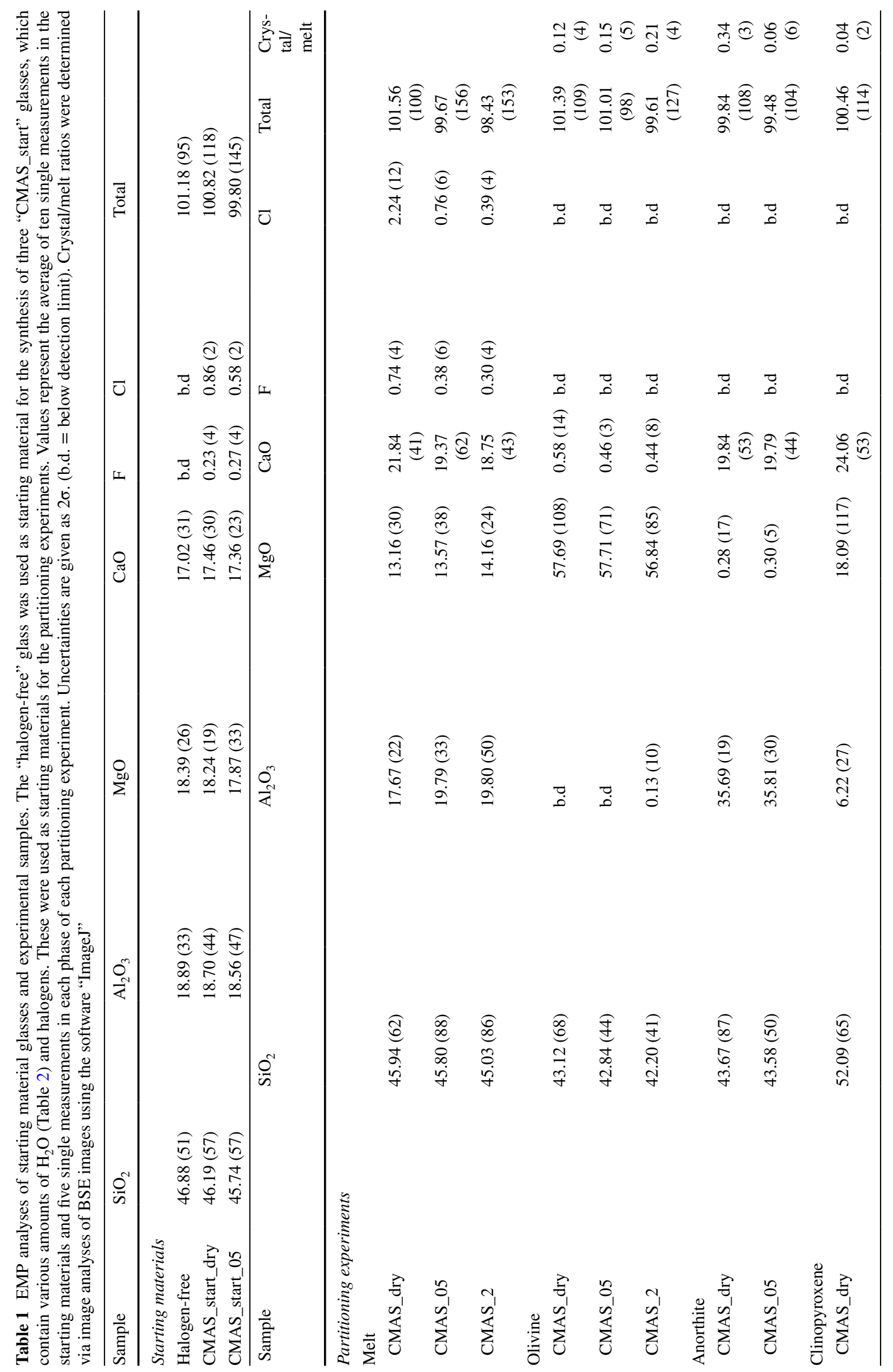


2015). This implies that most of the subducted chlorine is transported back to the surface by arc volcanism, whereas significant amounts of fluorine reach deeper portions of the Earth's mantle through subduction of oceanic lithosphere (Straub and Layne 2003; Joachim et al. 2015).

However, to date, none of the available fluorine and chlorine source region estimates consider the potential effect of water on the halogen partitioning behavior between olivine and melt. Bulk water abundance estimates for source peridotite beneath normal ridges (N-MORB) range from 50 to $250 \mathrm{ppm} \mathrm{H}_{2} \mathrm{O}$ (Michael 1988, 1995; Danyushevsky et al. 2000; Dixon et al. 2002; Saal et al. 2002; Simons et al. 2002; Hirschmann 2006; Green et al. 2014) and from 200 to 1100 ppm for $\mathrm{H}_{2} \mathrm{O}$ concentrations in OIB source regions (e.g., Dixon et al. 1997, 2002; Jamtveit et al. 2001; Hauri 2002; Hirschmann 2006; Green et al. 2014). Moreover, nominally dry high-pressure (Piston and Multianvil) experiments that simulate partial melting processes in mantle source regions to determine halogen partition coefficients are not perfectly dry (e.g., Kovács et al. 2012; Green et al. 2014). Minor amounts of volatiles might be introduced to the capsule as surface water adsorbed on to the grains of pre-dried powder. In addition, metal capsules are permeable to traces of water in high-pressure experimental assemblies at high P-T conditions (e.g., Patiño Douce and Beard 1994; Truckenbrodt and Johannes 1999; Kovács et al. 2012; Green et al. 2014), so that water stemming from the natural pressure medium (e.g., talc) may infiltrate the capsule during the experimental runs (Joachim et al. 2012). This implies that water may affect the halogen partitioning behavior between olivine and melt in MORB and OIB source regions as well as during "nominally dry" high-pressure experiments that simulate partial melting processes in these source regions.

In this study, we investigate the effect of water on the fluorine and chlorine partitioning behavior between olivine and silicate melt at $0.3 \mathrm{GPa}$ and $1280^{\circ} \mathrm{C}$. This allows us to evaluate the effect of water on fluorine and chlorine source region estimates and the potential consequences for our understanding of the Earth's mantle halogen and volatile cycle.

\section{Experimental methods}

\section{Rationale}

Partitioning experiments were performed in the $\mathrm{Fe}$-free $\mathrm{CaO}-\mathrm{MgO}-\mathrm{Al}_{2} \mathrm{O}_{3}-\mathrm{SiO}_{2}$ (CMAS)+F-Cl-Br-I- $\mathrm{H}_{2} \mathrm{O}$ system (Table 1). Knowledge about the effect of water on the halogen partitioning behavior between olivine and melt is a prerequisite for experimental setups that are able to control oxygen fugacities, e.g., using a double capsule technique (e.g., Boettcher et al. 1973; Matjuschkin et al. 2015). Thus, knowledge about the effect of water will enable us in a next step to introduce $\mathrm{Fe}$ at controlled oxygen fugacities to the system.

Defined amounts of water and halogens were added as $\mathrm{H}_{2} \mathrm{O}, \mathrm{CaF}_{2}, \mathrm{CaCl}_{2}, \mathrm{CaBr}_{2}$, and $\mathrm{CaI}_{2}$ (Tables 1, 2). Experiments were performed in a two-step approach using an Internally Heated Pressure Vessel (IHPV). First, hydrous, halogen bearing silicate glasses were synthesized at $1450^{\circ} \mathrm{C}$ and $0.2 \mathrm{GPa}$ to be used as starting materials. This method allows the exact determination of starting material compositions using the electron microprobe (EMP) for major element concentrations and infrared (IR) spectroscopy for bulk $\mathrm{H}_{2} \mathrm{O}$ abundances. All experiments were then performed in the same run, i.e., at identical P-T conditions $\left(1280^{\circ} \mathrm{C}, 0.3 \mathrm{GPa}\right)$ and with almost identical major element starting material composition (Table 1) but varying bulk water content (Table 2). Large crystals were obtained using the temperature oscillation technique (Erdmann and Koepke 2016). Back-scattered electron (BSE) images and EMP analyses were acquired to examine the phase assemblage and distribution in each sample. The water content in melt pools after the run as well as fluorine and chlorine concentrations in olivines and melt pools were determined using secondary ion mass spectrometry (SIMS). Fluorine and chlorine melt-pool concentrations were confirmed by the EMP analysis. This experimental procedure allows the determination of fluorine and chlorine partition coefficients between olivine and melt (Table 3) at bulk water contents ranging from 0.03 to $0.33 \mathrm{wt} \%$ (Table 2), and enables us to assess the effect of water on the partitioning behavior. Bromine and iodine abundances in olivines were below the detection limit of the methods and will be part of a subsequent contribution using a new analytical technique that will be based on the determination of halogen abundances by the analysis of noble gases produced by neutron irradiation (Johnson et al. 2000; Ruzié-Hamilton et al. 2015).

\section{Starting materials}

Starting materials were prepared from pure, analytical grade oxides, carbonates, and halides. First, dried $\left(105^{\circ} \mathrm{C}\right.$, $30 \mathrm{~min}) \mathrm{CaCO}_{3}, \mathrm{MgO}, \mathrm{Al}_{2} \mathrm{O}_{3}$, and $\mathrm{SiO}_{2}$ powders were thoroughly mixed in an agate mortar and heated to $1600^{\circ} \mathrm{C}$ for $3 \mathrm{~h}$ in a $1 \mathrm{~atm}$ chamber furnace using a platinum crucible. $105^{\circ} \mathrm{C}$ is not sufficient to remove magnesium hydroxide resulting in a small weight-in uncertainty. After quenching, the glass was ground, remixed, and reheated to $1600^{\circ} \mathrm{C}$ for $3 \mathrm{~h}$. The "halogen-free" starting material (Table 1) was split into three equal parts. Defined amounts of halides were added as $\mathrm{CaF}_{2}, \mathrm{CaCl}_{2}, \mathrm{CaBr}_{2}$, and $\mathrm{CaI}_{2}$ (Table 1) to each part. Glasses were reground, mixed to homogenize all components, dried at $105^{\circ} \mathrm{C}$ for at least $30 \mathrm{~min}$, and 
Table 2 Nominal water content of starting materials calculated from their initial weight; water content of glassy starting materials was determined using FTIR analysis (see text and Fig. 2 for details); water content of melt pools after partitioning experiments was determined using SIMS; bulk water contents after partitioning experiments were calculated assuming that the water content in crystalline phases is negligible compared to the water content of melt pools (see "Halogen incorporation mechanism in olivine" for details): $\left.\mathrm{H}_{2} \mathrm{O}_{\text {bulk-after experiment }}=\mathrm{H}_{2} \mathrm{O}_{\text {SIMS-melt pool }} \times(1 \text {-(crystal } / \text { melt })_{\text {total }}\right)$ with (crystal/melt) $_{\text {total }}$ being the bulk sample crystal/melt ratio derived from Table 1 . Uncertainties are given as $2 \sigma$

\begin{tabular}{|c|c|c|c|c|}
\hline Sample & $\begin{array}{l}\mathrm{H}_{2} \mathrm{O} \text { (nominal; starting mate- } \\
\text { rial; wt } \% \text { ) }\end{array}$ & $\mathrm{H}_{2} \mathrm{O}$ (FTIR; starting material; wt $\%$ ) & $\begin{array}{l}\mathrm{H}_{2} \mathrm{O} \text { (SIMS; melt pool; } \\
\text { wt } \% \text { ) }\end{array}$ & $\begin{array}{l}\mathrm{H}_{2} \mathrm{O} \text { (bulk - after } \\
\text { experiment; wt } \% \text { ) }\end{array}$ \\
\hline CMAS_dry & b.d & & $0.06(2)$ & $0.03(2)$ \\
\hline CMAS_05 & $0.23(2)$ & & $0.33(4)$ & $0.26(7)$ \\
\hline CMAS_2 & $0.30(3)$ & & $0.42(4)$ & $0.33(6)$ \\
\hline
\end{tabular}

Table 3 Fluorine and chlorine concentrations in olivine and melt were determined using SIMS. Fluorine and chlorine partition coefficients between olivine and silicate melt were calculated as $D^{\mathrm{ol} / \mathrm{melt}}$
$=C_{\text {crystal }} / C_{\text {melt }}$. Determination of uncertainties is described in detail in "Addition of water to experimental charges during preparation of high P-T experiments"

\begin{tabular}{lllllll}
\hline Sample & $\mathrm{F}_{\mathrm{ol}}(\mathrm{SIMS} ; \mathrm{ppm})$ & $\mathrm{Cl}_{\mathrm{ol}}(\mathrm{SIMS} ; \mathrm{ppm})$ & $\mathrm{F}_{\text {melt }}(\mathrm{SIMS} ; \mathrm{wt} \%)$ & $\mathrm{Cl}_{\text {melt }}(\mathrm{SIMS} ; \mathrm{wt} \%)$ & $\mathrm{D}_{\mathrm{F}}{ }^{\mathrm{ol} / \mathrm{melt}}\left(10^{-4}\right)$ & $\mathrm{D}_{\mathrm{Cl}}{ }^{\text {ol/melt }}\left(10^{-4}\right)$ \\
\hline CMAS_dry & $5.4(14)$ & $3.6(17)$ & $0.83(9)$ & $2.21(14)$ & $6.6(29)$ & $1.6(9)$ \\
CMAS_05 & $5.7(26)$ & $1.5(10)$ & $0.37(1)$ & $0.83(1)$ & $15.6(73)$ & $1.9(13)$ \\
CMAS_2 & $4.4(23)$ & $1.2(6)$ & $0.25(1)$ & $0.51(1)$ & $17.3(76)$ & $2.2(11)$ \\
\hline
\end{tabular}

subsequently filled into annealed platinum capsules of $4.8 \mathrm{~mm}$ inner diameter, $5.2 \mathrm{~mm}$ outer diameter, and $4 \mathrm{~cm}$ length. Defined small amounts of water (0.05 wt; $0.2 \mathrm{wt} \%$; Table 2) were added to two of the capsules using a micro syringe and the capsules were sealed shut immediately using a point welder. The third capsule was dried at $600^{\circ} \mathrm{C}$ for $1 \mathrm{~h}$ without addition of $\mathrm{H}_{2} \mathrm{O}$ before it was subsequently sealed shut to provide as dry conditions as possible.

Synthesis of starting materials and partitioning experiments was performed in an IHPV at the Leibniz University of Hannover, Germany. A detailed description of this apparatus is given in Berndt et al. (2002). The capsule was placed close to the maximum temperature position in the sample holder between two furnace controlling thermocouples (S-Type). Temperature at the capsule position was controlled by a third thermocouple (S-Type). For synthesis of starting materials, capsules were heated to $1450{ }^{\circ} \mathrm{C}$ at a constant pressure of $0.2 \mathrm{GPa}$ with argon gas used as pressure medium, and held for at least $14 \mathrm{~h}$. To avoid the formation of quench crystals during cooling, capsules were quenched rapidly by melting a platinum wire that held the capsule in place, so that the capsule dropped to the cold zone of the sample holder (Berndt et al. 2002). Following quenching, small glass fragments were separated from both ends of the glass cylinder and double polished for EMP and FTIR analyses (see "Textural observations and major element compositions"). The remaining glasses were reground in an agate mortar, dried at $105^{\circ} \mathrm{C}$ for at least $2 \mathrm{~h}$, and used for subsequent partitioning experiments.

\section{Partitioning experiments}

After a series of test experiments, $1280^{\circ} \mathrm{C}$ and $0.3 \mathrm{GPa}$ were chosen as ideal $\mathrm{P}-\mathrm{T}$ condition for the execution of all partial melting experiments presented in this study. At this $\mathrm{P}-\mathrm{T}$ condition, all samples reveal a mixture of large crystals embedded in silicate melt and a crystal/melt ratio of about $0.2-0.5$ (Table 1). This enables us to analyze the fluorine and chlorine concentrations in olivine and melt and the water concentration in the melt of each sample (Tables 1, 2, 3).

Dried starting materials (Table 1) were filled into annealed platinum capsules of $2.8 \mathrm{~mm}$ inner diameter and $3.2 \mathrm{~mm}$ outer diameter and $9 \mathrm{~mm}$ length, which were sealed shut immediately using a point welder. All experiments were performed in an IHPV located at the Leibniz University of Hannover. The three platinum capsules containing the three starting material compositions (Table 1) were placed in one sample holder, so that all three experiments with varying water contents were performed simultaneously in one run at identical pressure and temperature conditions. Pressure was kept constant at $300 \pm 5 \mathrm{MPa}$ throughout the run (pressure medium: dry argon gas). Experiments were first heated to the target temperature $\mathrm{T}_{\text {target }}=1280 \pm 2^{\circ} \mathrm{C}$ at a rate of $50^{\circ} \mathrm{C} / \mathrm{min}$ and held for $1 \mathrm{~h}$. Following this, the temperature was set to oscillate with a period of $1 \mathrm{~h}$ between $\mathrm{T}_{\text {target }}+20^{\circ} \mathrm{C}$ and $\mathrm{T}_{\text {target }}-20^{\circ} \mathrm{C}$ (Erdmann and Koepke 2016). After 48 temperature oscillation cycles (with a total duration of $48 \mathrm{~h}$ ), the temperature was kept constant for another $48 \mathrm{~h}$ to ensure equilibrium 
conditions. This method allows growth of large crystals (Fig. 1), which is a prerequisite for SIMS analysis. At the end of the runs, we applied the rapid quench technique to avoid nucleation of quench crystals (Berndt et al. 2002).

Quenched samples were polished, cleaned with ethanol and water, and mounted in pure indium following Hauri et al. (2002).

\section{Analyses}

\section{Electron microprobe}

Samples were analyzed using a Cameca SX 100 EMP located at the Leibniz University of Hannover, Germany. BSE images were used to determine grain sizes, textures, and crystal/melt ratios in each sample. Chemical compositions of crystals and melts were obtained by wavelength dispersive analysis. Operating conditions for all analyses of crystalline materials were $15 \mathrm{kV}$ acceleration voltage, $15 \mathrm{nA}$ beam current, $10 \mathrm{~s}$ counting time on the respective peak, and $10 \mathrm{~s}$ on background with focused beam. Glasses (starting materials and melt pools) were analyzed using a defocused beam $(5 \mu \mathrm{m})$ and $4 \mathrm{nA}$ beam current. Wellknown standards were used for EMPA calibration $(\mathrm{Mg}$ on $\mathrm{MgO}$; $\mathrm{Si}$ on wollastonite; $\mathrm{Al}$ on $\mathrm{Al}_{2} \mathrm{O}_{3} ; \mathrm{Ca}$ on wollastonite; $\mathrm{Cl}$ on $\mathrm{NaCl} ; \mathrm{F}$ on $\mathrm{SrF}_{2}$ ). Ten single spots in the glass of each starting material were analyzed. In the run products, five spots were taken in each phase of each sample with varying distance to the crystal-melt interfaces to determine the major element $\left(\mathrm{CaO}, \mathrm{MgO}, \mathrm{Al}_{2} \mathrm{O}_{3}, \mathrm{SiO}_{2}\right)$, fluorine, and chlorine concentrations (Table 1).

\section{Fourier transformation infrared spectroscopy (FTIR)}

Bulk water contents of starting materials were determined by Fourier Transformation Infrared Spectroscopy (FTIR). IR absorption spectra of doubly polished glass wafers with a thickness of 260-310 $\mu \mathrm{m}$ were recorded using a "Bruker IRscopeII" microscope connected to a "Bruker IFS88" FTIR spectrometer located at the University of Hannover, Germany. A Globar light source (MIR), $\mathrm{KBr}$ beam splitter, and a DTGS detector were used for each measurement. The measurement range was $2000-6000 \mathrm{~cm}^{-1} .50$ single scans were averaged per spectrum with a resolution of $2 \mathrm{~cm}^{-1}$. A slit aperture was used between the objective and the detector to limit the analyzed sample volume. The area selected by the slit was about $100 \times 100 \mu \mathrm{m}$ wide. For each starting material, five individual measurements were taken at different positions and averaged. Spectra were fitted using the "OPUS" software. Starting material bulk water contents were quantified from the peak height of the $\mathrm{OH}$ stretching vibration band at $3550 \mathrm{~cm}^{-1}$ (Fig. 2) after subtracting a linear base line following the method of Mercier et al. (2010)
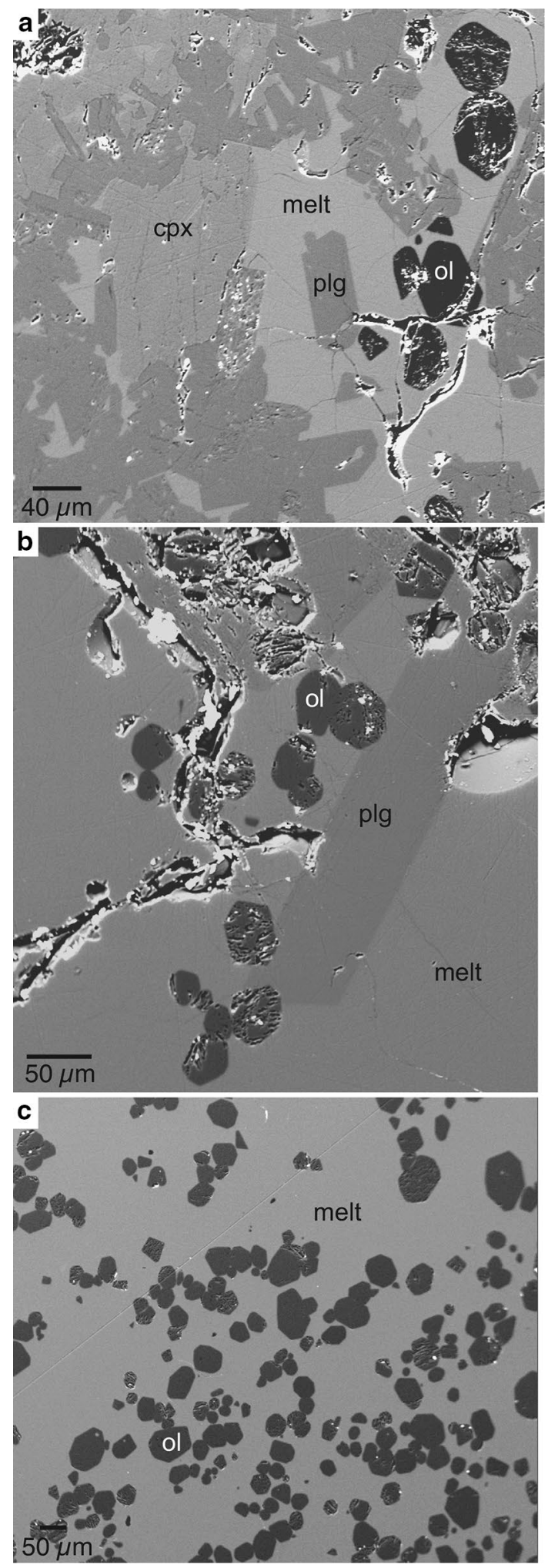

Fig. 1 Back-scattered electron images of IHPV runs showing a silicate melt containing a clinopyroxene, plagioclase, and olivine (CMAS_dry), b plagioclase, olivine (CMAS_05), and c olivine (CMAS_2) 


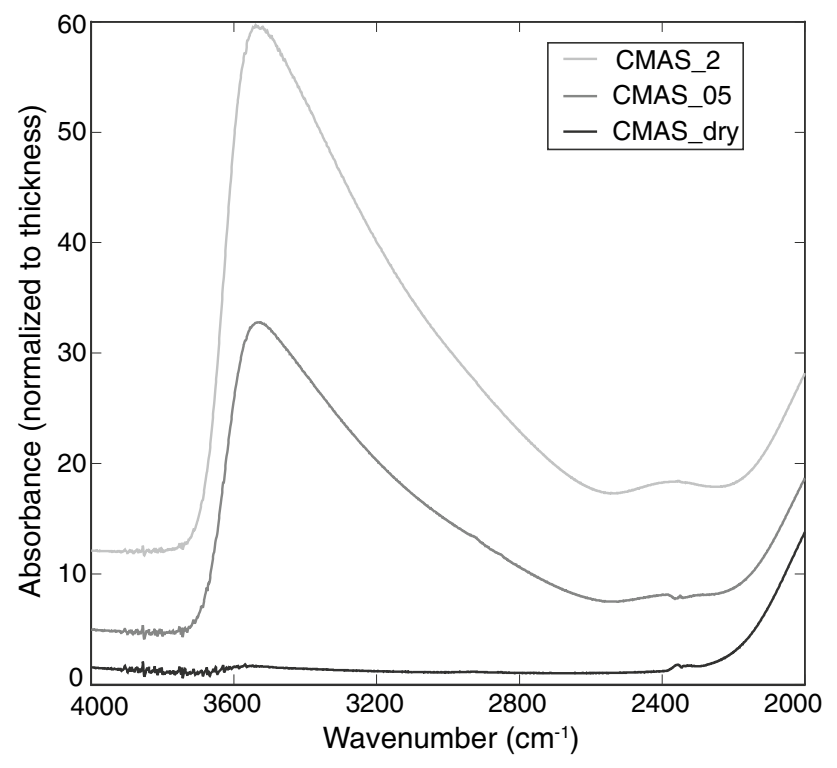

Fig. 2 FTIR spectra of glassy starting materials "CMAS_start_dry", "CMAS_start_05", and "CMAS_start_2" showing the wavenumber region of the $\mathrm{OH}$ stretching vibration band at $3550 \mathrm{~cm}^{-1}$

and using their FTIR absorptivity coefficient for basalt glass. Densities of basaltic glasses could not be determined directly due to the small sample volume but were estimated to $2.6 \pm 0.2 \mathrm{~g} / \mathrm{cm}^{3}$ (e.g., Mercier et al. 2010). The starting material bulk water contents presented in Table 2 represent the average of five single analyses taken at different positions of each starting material.

\section{Secondary ion mass spectrometry (SIMS)}

Fluorine and chlorine concentrations in olivine and melt Fluorine and chlorine concentrations of olivine crystals and glasses were determined in two separate sessions using a Cameca 1270 located at the University of Edinburgh, United Kingdom. First, samples were gold coated to provide electrical conductivity. Sample spots were pre-sputtered for $60 \mathrm{~s}$ at the beginning of each analysis to suppress surface contamination and amorphize the surface of crystalline materials. Pre-sputter and analytical conditions were identical. In total, in each sample, 10-30 single spots were analyzed in the olivines and 6-10 spots in the melt pools. Settings for all measurements are summarized as follows: $\mathrm{A} \mathrm{Cs}^{+}$primary ion beam with a primary current of $1 \mathrm{nA}$ was accelerated to $10 \mathrm{keV}$ and focused to a spot diameter of $\sim 5 \mu \mathrm{m}$. Negative secondary ions were accelerated to $10 \mathrm{keV}$ and analyzed using an electron multiplier detector with an energy width of $40 \mathrm{eV}$. Peak counting times were $4 \mathrm{~s}$ each for ${ }^{19} \mathrm{~F}$ and ${ }^{35} \mathrm{Cl}$, and $2 \mathrm{~s}$ for ${ }^{30} \mathrm{Si}$. Vacuum was set to $1 \cdot 10^{-7}$ mbar. Mass resolving power was adjusted to $\mathrm{M} / \Delta \mathrm{M} \approx 3000$, which is adequate to resolve ${ }^{19} \mathrm{~F}$ from the potential interferences of ${ }^{18} \mathrm{OH}$ and ${ }^{16} \mathrm{OH}_{3}$. The typical chal- lenging interference for the analysis of $\mathrm{Cl}$ is the $\mathrm{SH}$ molecule, which is not relevant in this study, because the system is sulfur free. Detection limits were about one ppm for both, fluorine and chlorine.

Fluorine and chlorine concentrations in minerals and melt pools were normalized to the ${ }^{30} \mathrm{Si}$ count rate and determined using the fluorine $(3000 \mathrm{ppm})$ and chlorine (7400 ppm) concentration of the "Halogen standard 3" reference material (Joachim et al. 2015). To verify the accuracy of this method, a BCR-2 g glass standard reference material (440 ppm fluorine; USGS certificate of analysis) and Lipari obsidian standard glass $(0.36 \mathrm{wt} \%$ chlorine; Hunt and Hill 1993; Kuehn et al. 2009) were analyzed before the measurement of each sample. Melt-pool fluorine and chlorine concentrations were also determined using EMP analysis (Table 1). These provide a first-order independent method for the determination of $\mathrm{F}$ and $\mathrm{Cl}$ meltpool abundances. Both methods give within uncertainty identical fluorine and chlorine concentrations (Tables 1, 3), confirming that SIMS analyses are within uncertainty accurate (Table 3 and "Addition of water to experimental charges during preparation of high P-T experiments").

The amorphous structure and composition of basaltic glasses (melt pools) is directly comparable to the composition and structure of the basalt glass "Halogen standard 3" (Joachim et al. 2015), so that, for this phase, only the uncertainty of the analytical method (SIMS) and the reproducibility of the measurements were considered for the determination of total analytical uncertainties. The pre-sputter process amorphizes crystalline materials, so that relative sensitivity factors of glassy standard materials can likely be applied to crystalline and amorphous materials (e.g., Stephan and Lyon 2013). A detailed study, which compares matrix effects of glass standards with defined halogen concentrations used for the analyses of crystalline samples, is, however, still missing. To make sure that the potential for a systematic error stemming from this matrix effect is adequately covered by the total uncertainty, we applied an additional conservative uncertainty of a factor of two for the determination of fluorine and chlorine abundances in olivines, following Joachim et al. (2015).

$\mathrm{H}_{2} \mathrm{O}$ melt-pool concentration Hydrogen concentrations in the melt pools were determined with a Cameca ims3f ion probe at Heidelberg University using a ${ }^{16} \mathrm{O}^{-}$primary ion beam with a net energy of $14.5 \mathrm{keV}$, a beam current of $10 \mathrm{nA}$ and a spot diameter of $\sim 15 \mu \mathrm{m}$. Positive secondary ions were accelerated to $4.5 \mathrm{keV}$ with an offset of $75 \mathrm{eV}$ (energy filtering), an energy window width of $40 \mathrm{eV}$, and a mass resolving power of $\mathrm{M} / \Delta \mathrm{M} \approx 400$. To minimize in situ hydrogen contamination, the area analyzed was limited to $\sim 6 \mu \mathrm{m}$ (nominal imaged field $25 \mu \mathrm{m}$; field aperture $400 \mu \mathrm{m}$ ) and a liquid nitrogen cold trap in the sample chamber was 
used. Prior to 6 analysis cycles with an integration time of $3 \mathrm{~s}$ for $\mathrm{H}^{+}$and ${ }^{30} \mathrm{Si}^{+}$per cycle, the sample was pre-sputtered for $240 \mathrm{~s}$ to remove the initial water and hydrocarbon surface contamination. The $\mathrm{H}^{+}$background signal due to in situ contamination was equivalent to $\leq 50 \mu \mathrm{g} / \mathrm{g} \mathrm{H}_{2} \mathrm{O}$ and at least a factor 10 below the lowest value analyzed (CMAS_dry: $0.06 \mathrm{wt} \%$, Table 2). At a sensitivity of $\sim 1 \mathrm{cps} \mathrm{H}^{+}$for $1 \mu \mathrm{g} / \mathrm{g}$ $\mathrm{H}_{2} \mathrm{O}$, the detection limit of this analytical setup was dominated by the intensity of the background signal. Because of the high $\mathrm{H}_{2} \mathrm{O}$ concentrations, it was not necessary to determine (and correct for) the rate of in situ contamination (see Ludwig and Stalder 2007 for a more detailed description of the setup). Quantification was done using relative ion yields (reference isotope ${ }^{30} \mathrm{Si}$ ) with a hydrated glass $\left(5.9 \mathrm{wt} \% \mathrm{H}_{2} \mathrm{O}\right.$, equivalent to glass ' $\mathrm{CG} 1$ ' in Acosta-Vigil et al. 2006) as reference material.

\section{Results}

\section{Textural observations and major element compositions}

EMPA results show that all starting materials are homogeneous glasses and have within uncertainty identical major element concentrations (Table 1). FTIR results show that the bulk water content of the dry starting material is below the detection limit of the method $(<0.1 \mathrm{wt} \%$, Mercier et al. 2010). Glassy starting materials for experiments CMAS_05 and CMAS_2 show a bulk water concentration that is about $0.1-0.18 \mathrm{wt} \%$ higher than the bulk water concentration expected from their nominal weight (Table 2). After the run, melt-pool concentrations show a slight elevation of the bulk water content of 0.06-0.12 wt\% compared to bulk water abundances in the respective starting materials before the partitioning experiment (Table 2).

EMP analyses reveal that olivines are forsterites with a small amount of $\mathrm{Ca}$ substituting for $\mathrm{Mg}$ in the crystal lattice (Table 1); plagioclases are anorthite and pyroxenes are clinopyroxene. Crystals in all experiments appear homogeneous (Fig. 1). EMP analyses at five different spots in each crystalline phase show little variation (Table 1), indicating that crystals do not have any major element concentration gradients. The three experiments vary significantly regarding their phase assemblage and crystal/melt ratio (Table 1). The nominally dry experiment "CMAS_dry" shows a mixture of olivine, plagioclase and pyroxene with a crystal/ melt ratio of 0.48 (3) (Fig. 1a). BSE images of this experiment reveal that all crystals are predominantly euhedral and of rectangular shape. A few plagioclases show voids. Olivines and plagioclases have a side length of 30-60 $\mu \mathrm{m}$; pyroxenes are larger and have a side length of up to $120 \mu \mathrm{m}$ (Fig. 1a).
Sample "CMAS_05" shows a significantly lower crystal/ melt ratio of 0.21(6). Observed crystals are predominantly euhedral olivines of rectangular shape with a side length of about $40 \mu \mathrm{m}$ (Fig. 1b). The sample also shows a few isolated, euhedral plagioclase crystals of rectangular shape that reach a side length of more than $150 \mu \mathrm{m}$ (Fig. 1b). In contrast to sample "CMAS_dry", no pyroxene was observed in sample "CMAS_05".

Sample "CMAS_2" shows euhedral olivines, which are identical in shape, size, distribution, and major element composition to the ones observed in sample "CMAS_05" (Table 1; Fig. 1c). The crystal/melt ratio of sample "CMAS_2" (0.21(4)) is within uncertainty also identical to the ratio in sample "CMAS_05". However, olivine is the only crystalline material in sample "CMAS_2"; neither plagioclase nor pyroxene was observed. Melt pools in all samples appear homogeneous.

EMP analyses taken at five different spots in the melt pools of each sample show only little variation (Table 1) and give no indication for a depletion or enrichment of any element adjacent to the crystals. Variations in meltpool compositions between different experiments are dependent on the crystal/melt ratio and the observed phase assemblage.

\section{Addition of water to experimental charges during preparation of high $\mathrm{P}-\mathrm{T}$ experiments}

Halogen-free melt was produced by heating a homogeneous halogen-free powder mix to $1600{ }^{\circ} \mathrm{C}$ in an open $\mathrm{Pt}$ crucible. Due to the high temperature, we may certainly assume that the halogen-free glass is almost completely dry. Water and halogen bearing glassy starting materials show actual bulk water concentrations determined using FTIR analyses (Table 2) that are $0.1-0.18$ wt\% higher than expected from their initial weight. The difference may be explained by the fact that adsorbed surface water is introduced in significant amounts to the assembly during capsule preparation mainly through strongly hygroscopic calcium-halide powders. Usage of dried starting materials (at $105^{\circ} \mathrm{C}$ ) and subsequent welding of the filled capsule is not sufficient to avoid the addition of surface water. IR spectra of the halogen bearing dry starting material (CMAS_dry) reveal that the bulk water content of this sample is lower than the detection limit of this method $(<0.1 \mathrm{wt} \%$, Mercier et al. 2010). In contrast to the water bearing starting materials, this starting material was dried at $600^{\circ} \mathrm{C}$ and welded shut within $60 \mathrm{~s}$ after removing it from the furnace, because no addition of water was required.

Melt-pool water contents after partial melting experiments were determined using SIMS. As a first order approximation, it is assumed that water behaves almost perfectly incompatibly and is completely distributed into the melt 
pools. Considering crystal/melt ratios, bulk sample water contents after the experiments were calculated according to $\mathrm{H}_{2} \mathrm{O}_{\text {bulk }- \text { after experiment }}=\mathrm{H}_{2} \mathrm{O}_{\text {SIMS-melt pool }} \times(1$ - (crystal/ melt $)_{\text {total }}$ ) with (crystal/melt) total $_{\text {being }}$ the bulk sample crystal/melt ratios (Table 1). Bulk sample water contents are within uncertainty identical to starting material bulk water concentrations determined using FTIR (Table 2). The general trend seems to indicate the addition of very small amounts of water to the experimental charges through adsorbed surface water, because average bulk $\mathrm{H}_{2} \mathrm{O}$ concentrations are 0.03-0.04 wt\% higher compared to starting material bulk $\mathrm{H}_{2} \mathrm{O}$ concentrations. However, addition of such small amounts is within the uncertainty of the analysis.

\section{Effect of water on fluorine and chlorine partitioning behavior between olivine and melt}

We considered only monocrystalline, large, euhedral olivines for SIMS analyses. Nevertheless, a few single analyses of olivine crystals show ${ }^{19} \mathrm{~F} /{ }^{30} \mathrm{Si}$ and ${ }^{35} \mathrm{Cl} /{ }^{30} \mathrm{Si}$ ratios that are an order of magnitude or more above the respective average ratio. It cannot be excluded that small melt fragments are part of the ablated material. Owing to the incompatible behavior of fluorine and chlorine, even the ablation of very small glass fragments causes a significant increase of the respective halogen $/{ }^{30} \mathrm{Si}$ ratio. Single measurements of olivine that show a significant increase of an order of magnitude or more in both, the ${ }^{19} \mathrm{~F} /{ }^{30} \mathrm{Si}$ and ${ }^{35} \mathrm{Cl} /{ }^{30} \mathrm{Si}$ ratio, are therefore, interpreted as being affected by glass fragments and were not considered further.

Fluorine and chlorine partition coefficients ( $D_{X}^{\text {olivine/melt }}$ ) were calculated from the halogen concentrations in olivine $\left(C_{X}^{\text {olivine/melt }}\right)$ and corresponding quenched melt $\left(C_{X}^{\text {melt }}\right)$ according to $D_{X}^{\text {olivine/melt }}=C_{X}^{\text {olivine }} / C_{X}^{\text {melt }}$ (Table 3 ). In contrast to absolute fluorine and chlorine concentrations, determination of partition coefficients is not dependent on the quality of standard materials as potential inaccuracies would affect the determination of absolute halogen concentrations in both, olivine and glass, in an identical manner, if we exclude a potential matrix effect.

The fluorine partitioning behavior between olivine and melt increases linearly with increasing water content (bulk sample water content: 0.03(2)-0.33(6) wt $\% \mathrm{H}_{2} \mathrm{O}$; see Table 3 and "Halogen incorporation mechanism in olivine' for details) and may be described at $1280^{\circ} \mathrm{C}$ and $0.3 \mathrm{GPa}$ with $\left(R^{2}=0.99\right)$ :

$D_{F}^{\text {ol/melt }}=3.6 \pm 0.4 \times 10^{-3} \times X_{\mathrm{H}_{2} \mathrm{O}}+6 \pm 0.4 \times 10^{-4}$

with $\mathrm{X}_{\mathrm{H} 2 \mathrm{O}}$ being the bulk sample water content in wt\%. Uncertainties are given as $1 \sigma$. The slope of this function is not affected by a potential matrix effect, because this would be identical in all analyzed samples.

The presence of water has, within uncertainty, no effect on the chlorine partitioning behavior between olivine and melt at $0.3 \mathrm{GPa}$ and $1280^{\circ} \mathrm{C}$ (Fig. 3).

\section{Discussion}

\section{Halogen incorporation mechanism in olivine}

The experiments presented in this study were not specifically designed to determine the fluorine and chlorine incorporation mechanism in olivine. The observed partitioning behavior gives, however, strong indications regarding the fluorine incorporation mechanism. A potential mechanism is the $\left[\mathrm{MgO}_{2}\right]^{2-}=\left[\mathrm{F}_{2}\right]^{2-}$ substitution (Bernini et al. 2013), an analog mechanism of $\mathrm{OH}$ incorporation in olivine, in which protonation of oxygen coupled with the formation of $\mathrm{Mg}$ vacancies in the octahedral site is the predominant mechanism (Smyth et al. 2006).

A second potential mechanism is the replacement of a $\left[\mathrm{SiO}_{4}\right]^{4-}$ tetrahedron by a $\left[\mathrm{F}_{4}\right]^{4-}$ quadruplet, as proposed

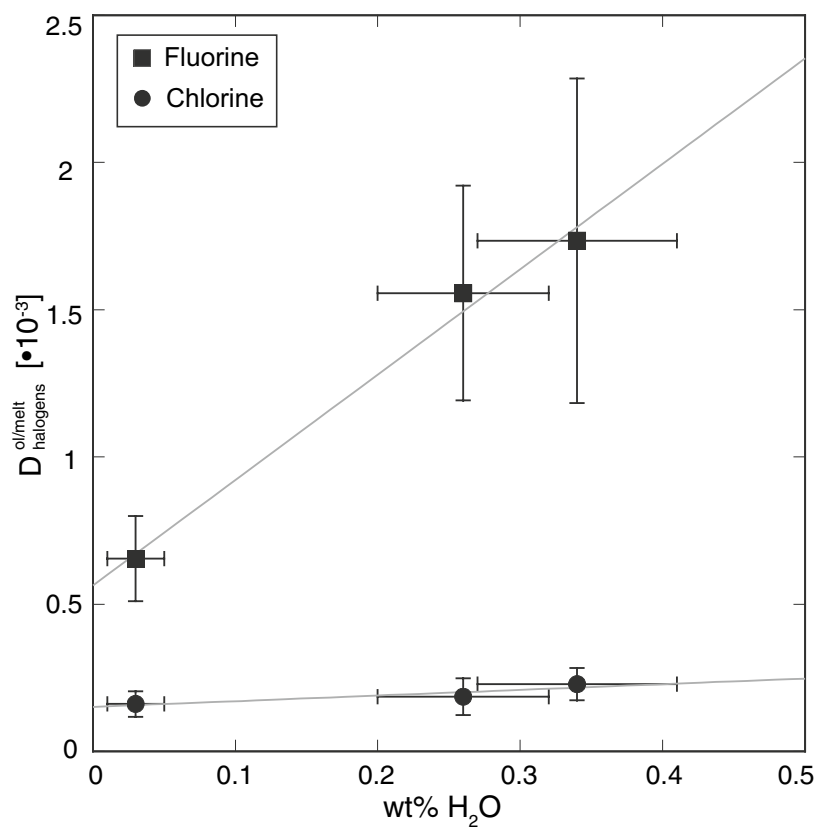

Fig. 3 Plot of fluorine and chlorine partition coefficients between olivine and silicate melt (Table 3) vs. the sample bulk water content after partitioning experiments (Table 2). All experiments were performed in one run, i.e., at identical P-T conditions of $1280^{\circ} \mathrm{C}$ and $0.3 \mathrm{GPa}$. Fluorine partition coefficients increase linearly with increasing bulk water content, whereas the chlorine partitioning behavior is, within uncertainty, not affected by the presence of water between bulk water contents of 0.03 (2) and 0.33 (6) wt $\% \mathrm{H}_{2} \mathrm{O}$ 
for fluorine incorporation in calcic and magnesian garnets (Valley et al. 1983; Smyth et al. 1990; Visser 1993). Using first-principle calculation, Bernini (2011) showed that this substitution mechanism increases the solubility of fluorine in forsterite exponentially with increasing temperature, whereas the effect of pressure is almost negligible. Bernini (2011) did not consider a potential effect of pressure on the incorporation mechanism of fluorine into olivine in dependence of varying bulk $\mathrm{H}_{2} \mathrm{O}$. However, the solubility behavior is in agreement with the observed temperature dependent fluorine partitioning behavior described in Joachim et al. (2015; see also Fig. 4a of this study). Xue et al. (2016) have used ${ }^{1} \mathrm{H}$ NMR measurements and first-principles calculations to show that the dominant $\mathrm{H}$ substitution mechanism in forsterite at $1200{ }^{\circ} \mathrm{C}$ and $12 \mathrm{GPa}$ is $[\mathrm{Si}]^{4+}=[\mathrm{H}]^{4+}$.

Based on FTIR analyses of water and fluorine bearing olivine crystals, Crépisson et al. (2014) suggested a coupled incorporation mechanism of fluorine and hydrogen in forsterite. In the presence of water, clumped $\mathrm{OH} / \mathrm{F}$ defects are formed that are coupled with the formation of a $[\mathrm{Si}]^{4+}$ vacancy. Results of their study show that clumped $\mathrm{OH} / \mathrm{F}$ defects increase the defect stability compared to solely hydrolytic weakening (Brodholt and Refson 2000), so that the combined incorporation of fluorine and hydrogen in the olivine structure increases the partitioning of fluorine into olivine. This behavior is in excellent agreement with results of this study, which show that fluorine partitioning into olivine increases linearly with increasing bulk water content. This strongly implies that $\left[\mathrm{SiO}_{4}\right]^{4-}=\left[(\mathrm{F}+\mathrm{OH})_{4}\right]^{4-}$ is the dominant substitution mechanism for fluorine and water incorporation in olivine. However, it should be noted that this study as well as the study of Crépisson et al. (2015) was performed in a Fe-free model system. Future studies are strongly required that investigate the potential effect of $\mathrm{Fe}$ (and oxygen fugacity) on the fluorine incorporation mechanism in olivine.

In contrast to fluorine, within uncertainty, there is no effect of the bulk water content on chlorine partitioning behavior. An explanation for the different behavior might be that $\mathrm{Cl}$ is incorporated via another mechanism in the olivine structure, such as $\left[\mathrm{MgO}_{2}\right]^{2-}=\left[\mathrm{Cl}_{2}\right]^{2-}$. However, specifically designed experiments combined with structural refinement methods (such as NMR spectroscopy) are required for a better understanding of the exact incorporation mechanism.

\section{Effect of water on estimates of fluorine and chlorine OIB source region concentrations}

\section{Chlorine}

Results of this study show that within uncertainty, in the model system $\mathrm{CMAS}+\mathrm{F}+\mathrm{Cl}+\mathrm{Br}+\mathrm{I}+\mathrm{H}_{2} \mathrm{O}$, there is no
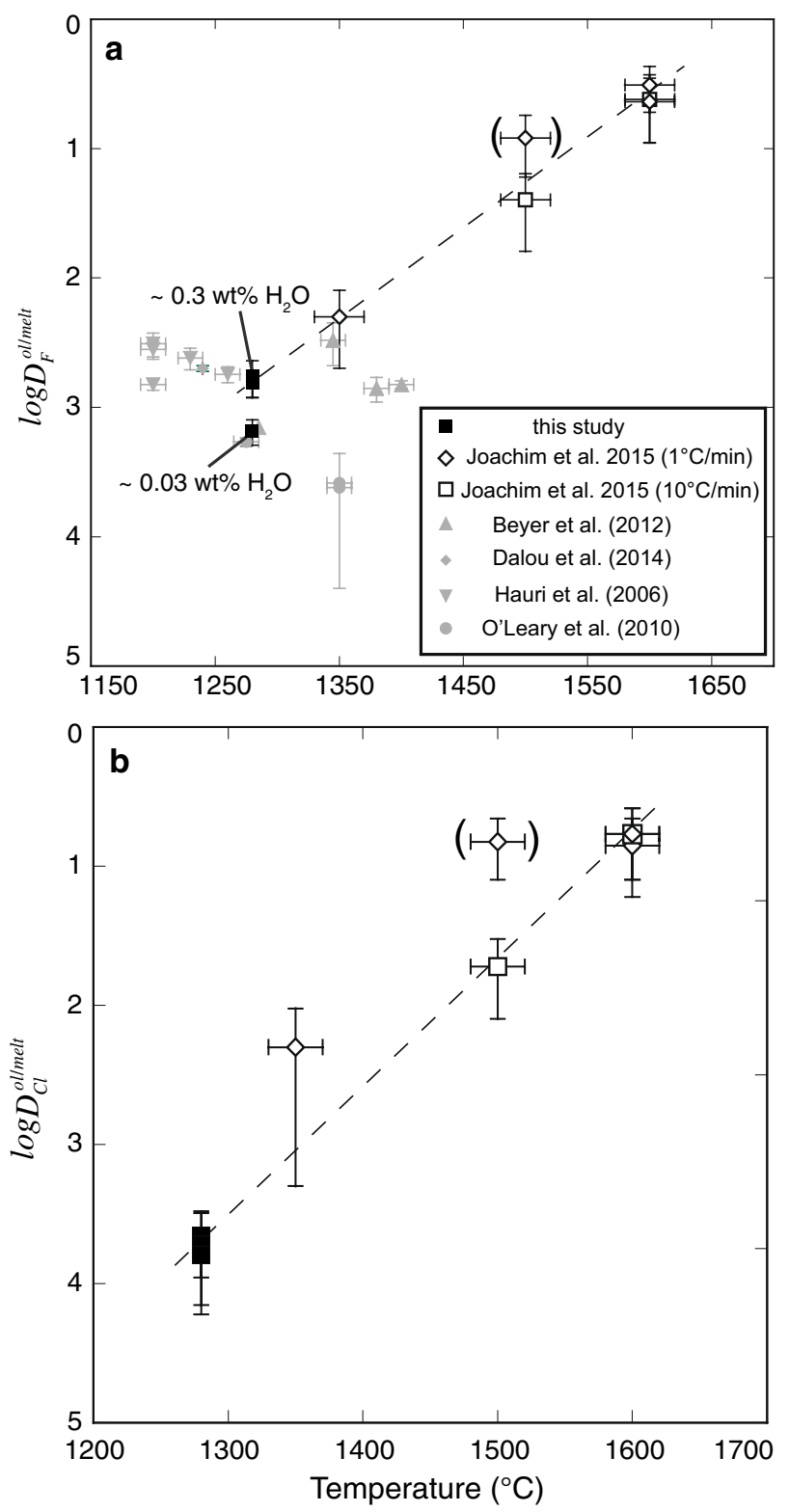

Fig. 4 Plots of temperature vs. a fluorine and $\mathbf{b}$ chlorine partition coefficients between olivine and silicate melt. Dashed lines represent the best fit through the data of Joachim et al. (2015) and this study excluding the overestimated slow-cooled sample targeting at $1500^{\circ} \mathrm{C}$ (cooled to target temperature with $1{ }^{\circ} \mathrm{C} / \mathrm{min}$; in parentheses; see Joachim et al. 2015 for details) and in (a) the almost dry sample (CMAS_dry; 0.03 (2) wt $\% \mathrm{H}_{2} \mathrm{O}$ ) of this study. A detailed discussion is provided in "Potential effect of water on fluorine concentrations and $\mathrm{F} / \mathrm{H}_{2} \mathrm{O}$ ratios during partial melting in the upper mantle". Note that experiments of Joachim et al. (2015) and this study were performed between 0.3 and $2.3 \mathrm{GPa}$, implying that the effect of pressure is negligible in this range. The following equations describe the, a fluorine partitioning behavior between olivine and silicate melt in the presence of a bulk water content of approximately $0.2-0.3 \mathrm{wt} \% \mathrm{H}_{2} \mathrm{O}$ and $\mathbf{b}$ chlorine partitioning behavior that is not affected by the bulk water content: $\mathbf{a} D_{\mathrm{ol} / \mathrm{melt}}^{\mathrm{F}}=3 \mathrm{E}-12 \mathrm{e}^{0.0157 \times \mathrm{T}\left({ }^{\circ} \mathrm{C}\right)}\left(R^{2}=0.99\right) ; \mathbf{b D} \mathrm{ol} / \mathrm{melt}$ $=4 \mathrm{E}-16 \mathrm{e}^{0.0211 \times \mathrm{T}\left({ }^{\circ} \mathrm{C}\right)}\left(R^{2}=0.99\right)$ 
effect of the bulk water content on the chlorine partitioning behavior between olivine and melt at $1280^{\circ} \mathrm{C}, 0.3 \mathrm{GPa}$ and bulk water contents ranging from 0.03 (2)-0.33 (6) wt\%. Figure $4 \mathrm{~b}$ shows that the chlorine partition coefficients determined in this study are perfectly in line with the temperature dependence of the chlorine partitioning behavior presented in Joachim et al. (2015). The data suggest that chlorine partitioning into olivine increases by three orders of magnitude between 1250 and $1600{ }^{\circ} \mathrm{C}$ (Fig. 4b), thus covering the complete temperature range relevant for partial melting processes in MORB and OIB source regions. Joachim et al. (2015) showed that the effect of pressure is negligible between 1.0 and $2.3 \mathrm{GPa}$. The fact that derived partition coefficients of this study are perfectly in line with the results of Joachim et al. (2015) implies that the effect of pressure is negligible down to at least $0.3 \mathrm{GPa}$. Consequently, at least in the simplified Fe-free CMAS + F-Cl-Br$\mathrm{I}-\mathrm{H}_{2} \mathrm{O}$ system, temperature is the only parameter that needs to be considered for the determination of chlorine partition coefficients between olivine and melt at uppermost mantle conditions.

\section{Fluorine}

In contrast to chlorine, the bulk water content does affect the fluorine partitioning behavior between olivine and silicate melt in the Fe-free model system $\mathrm{CMAS}+\mathrm{F}+\mathrm{Cl}+\mathrm{Br}+\mathrm{I}+\mathrm{H}_{2} \mathrm{O}$ (Figs. $3,4 \mathrm{a}$ ) and thus potentially the estimates for fluorine concentrations in MORB and OIB source regions.

Figure $4 \mathrm{a}$ shows that fluorine partition coefficients for a bulk water content of 0.26 (7) -0.33 (6) wt $\% \mathrm{H}_{2} \mathrm{O}$ (CMAS_05 and CMAS_2; Table 2) are perfectly in line with the temperature dependence of the fluorine partitioning behavior between olivine and melt presented in Joachim et al. (2015). The partition coefficient of the slow-cooled sample at $1500^{\circ} \mathrm{C}$ (in parentheses in Fig. 4a) does not represent equilibrium conditions, and is, therefore, excluded from the fit (see Joachim et al. (2015) for a detailed explanation). The data point at almost dry conditions (0.03 (2) wt $\%$ bulk $\mathrm{H}_{2} \mathrm{O}$ ), however, does not fit with the temperature trend presented in Joachim et al. (2015). This indicates that nominally dry piston-cylinder experiments (Joachim et al. 2015) were not dry but had a bulk water content at a level comparable to the water-doped experiments $\left(\sim 0.2-0.3\right.$ wt $\%$ bulk $\left.\mathrm{H}_{2} \mathrm{O}\right)$ presented in this study (Table 1; Fig. 4a). The preparation procedures for halogendoped glass powder starting materials used in Joachim et al. (2015) and the water-doped experiments presented in this study (CMAS_05 and CMAS_2, Table 2) were almost identical, implying that about $0.1 \mathrm{wt} \%$ bulk $\mathrm{H}_{2} \mathrm{O}$ was likely introduced as surface water to the experimental charges. With Pt capsules being permeable to traces of water in piston-cylinder assemblies at high $\mathrm{P}-\mathrm{T}$ conditions (Patino Douce and Beard 1994; Truckenbrodt and Johannes 1999; Joachim et al. 2012), additional water present in the samples of the Joachim et al. (2015) study potentially infiltrated from the hydrous pressure medium (talc) into the capsule during the run resulting in a bulk water content of about $0.2-0.3 \mathrm{wt} \% \mathrm{H}_{2} \mathrm{O}$. Fluorine partitioning data provided by Hauri et al. (2006) and Dalou et al. (2014) are about 0.5 orders of magnitude above the trend shown in Joachim et al. (2015). This might be explained by the fact that these samples had a melt water content of 1.7-25 and $2.6 \mathrm{wt} \%$, respectively, which would further increase fluorine partitioning into olivine.

Based on the results of this study, we are able to estimate, for the first time, the order of magnitude of the effect of water on fluorine mantle source region estimates. To this end, several assumptions have been made:

- We assume that the fluorine partition coefficient between olivine and silicate melt increases linearly with increasing bulk water content with the observed slope (Fig. 3) independent of pressure and temperature variations, i.e., that the observed effect of water on the fluorine partitioning behavior is valid at $\mathrm{P}-\mathrm{T}$ conditions representing partial melting processes in MORB and OIB source regions.

- We assume that the piston-cylinder experiments presented in Joachim et al. (2015) contain a bulk water content of about $0.3 \mathrm{wt} \% \mathrm{H}_{2} \mathrm{O}$ (Fig. 4a).

- We consider only the effect of water on the fluorine partitioning behavior between olivine and melt. Further studies are required to confirm that there is no potential effect of water on the partitioning behavior between other major mantle mineral phases and melt.

- We use the model of accumulated fractional melting developed by Shaw (1970) to estimate fluorine concentrations in MORB and OIB source regions. We are aware of the fact that this is a simplified model that does not consider incongruent melting of the Earth's mantle. However, this reference model has also been used by Beyer et al. (2012) and Joachim et al. (2015) and allows direct comparison of our results with results of these studies. Furthermore, due to the simplifications of available experimental data (Fe-free CMAS system used as mantle analog; unknown effect of other volatiles, such as $\mathrm{CO}_{2}$, on the water activity and thus halogen partitioning; analytical uncertainties particularly in determining halogen concentrations in olivine using SIMS (matrix effect); and potential effect of water on fluorine partitioning between other mantle minerals, such as opx, cpx or garnet, and melt), use of a more sophisticated model would at this stage not improve the quality of absolute source region estimates. 
MORB and OIB source region fluorine estimates were calculated as described in Joachim et al. (2015), with identical input parameters except the consideration of the effect of water on the fluorine bulk partitioning behavior between olivine and melt. This allows us to directly compare the estimated fluorine source region concentrations of this study with estimates presented in Joachim et al. (2015).

In MORB source regions, $\mathrm{H}_{2} \mathrm{O}$ bulk concentrations ranging from 50 to $250 \mathrm{ppm}$ are based on determinations of $\mathrm{H}_{2} \mathrm{O}$ /Ce ratios, $\mathrm{H}_{2} \mathrm{O}$ bulk analyses, and an experimental approach (e.g., Michael 1988, 1995; Danyushevsky et al. 2000; Dixon et al. 2002; Saal et al. 2002; Simons et al. 2002; Hirschmann 2006; Green et al. 2014). If we consider a minimum $\mathrm{H}_{2} \mathrm{O}$ bulk concentration of $50 \mathrm{ppm}$ in MORB source regions, the bulk fluorine partition coefficient is estimated to be $\mathrm{D}_{\mathrm{F}}(\mathrm{MORB}$ source $) \approx 0.004$, which is only marginally lower than the estimate of 0.005 given in Joachim et al. (2015). Using this new average bulk partition coefficient, the MORB source region bulk fluorine concentration is calculated to be $3-14 \mathrm{ppm}$. There is no significant difference between this estimate and the estimate presented in Joachim et al. (2015), indicating that the effect of water on the fluorine partitioning behavior between olivine and melt is negligible for the determination of fluorine MORB source region concentrations. If we consider a higher bulk water concentration in MORB source regions, this would result in an even smaller effect of water on the bulk fluorine partition coefficient, because experimental samples of Joachim et al. (2015) contained a bulk water content of about $0.2-0.3$ wt $\% \mathrm{H}_{2} \mathrm{O}$ (Fig. $4 \mathrm{a}$ ).

Geochemical studies of OIBs and oceanic plateaus (Dixon et al. 1997, 2002; Jamtveit et al. 2001; Hauri 2002; Nichols et al. 2002; Wallace et al. 2002; Seaman et al. 2004) of MORB that incorporate a plume-associated source component (Dixon et al. 2002) and an experimental approach (Green et al. 2014) suggest $\mathrm{H}_{2} \mathrm{O}$ concentrations in plume sources ranging from 200 to $1100 \mathrm{ppm}$. If we consider a minimum $\mathrm{H}_{2} \mathrm{O}$ bulk concentration of $200 \mathrm{ppm}$ $\mathrm{H}_{2} \mathrm{O}$, the bulk fluorine partition coefficient is estimated to be $\mathrm{D}_{\mathrm{F}}(\mathrm{OIB}$ source $) \approx 0.07$, which is 0.01 lower than the estimate given in Joachim et al. (2015). This results in an OIB source region fluorine concentration estimate of $30-70 \mathrm{ppm}$, which is about $10 \%$ lower than the estimate given in Joachim et al. (2015) that did not consider the effect of water. Consequently, results of this study show that water does affect the bulk fluorine partitioning behavior in OIB source regions and needs to be considered when estimating fluorine OIB source region concentrations. This includes the quantity of water present in the mantle as well as the amount of water that is introduced into sample charges during preparation and execution of nominally dry high-pressure-temperature experiments.
The estimate in this study does not consider the potential effect of water on the fluorine and chlorine partitioning behavior between pyroxenes or garnet and melt. A preliminary model presented by Dalou et al. (2014) considers the effect of water on the fluorine and chlorine partitioning behavior between opx, cpx, garnet, and melt, and predicts that the $\mathrm{Cl} / \mathrm{F}$ ratio of melts increases with increasing fluid fraction, which may indicate that water affects the fluorine and/or chlorine partitioning behavior. Experiments of that study were, however, not only performed with varying melt water contents but also at different temperatures, which may strongly affect the partitioning behavior (Joachim et al. 2015). Results of other studies seem to indicate that there is no effect of water on the fluorine partitioning behavior between orthopyroxene and melt (Hauri et al. 2006), clinopyroxene and melt (O'Leary et al. 2010; Beyer et al. 2016), or garnet and melt (Hauri et al. 2006; Beyer et al. 2016) at Earth's mantle conditions. Our study also does not consider a potential effect of iron (and $f \mathrm{O}_{2}$ ) on the partitioning behavior. Further studies are urgently required to determine the effect of such parameters. This will enable us to improve estimates of halogen abundances in MORB and OIB source regions and to better constrain recycling rates into and the distribution of volatiles within the Earth's mantle.

\section{Potential effect of water on fluorine concentrations and $\mathrm{F} / \mathrm{H}_{2} \mathrm{O}$ ratios during partial melting in the upper mantle}

In a recent study, Beyer et al. (2016) discuss a potential process to generate magmas with a high $\mathrm{F} / \mathrm{H}_{2} \mathrm{O}$ ratio in the upper mantle. In their model, bulk fluorine and water partition coefficients between mantle minerals and melt are kept constant regardless of potential effects of pressure, temperature, or bulk water content. Results of the model imply that multiple episodes of small degree melting are required to deplete a residual mantle more in $\mathrm{H}_{2} \mathrm{O}$ than in fluorine and thus obtain high $\mathrm{F} / \mathrm{H}_{2} \mathrm{O}$ ratios between 0.1 and 0.9 .

Results of this study show that the fluorine partitioning behavior between olivine and melt is affected by the bulk water content. Olivine is the most abundant mineral in peridotite with a modal abundance of $62 \%$ (McDonough 1990). This implies that variations in the fluorine partitioning behavior between olivine and melt may potentially play an important role in the generation of magmas containing a high fluorine concentration and a high $\mathrm{F} / \mathrm{H}_{2} \mathrm{O}$ ratio.

Consider a scenario where small amounts of water ( $<1 \mathrm{wt} \%$ bulk water content) are added to a dry peridotitic system in the Earth's upper mantle. This will decrease the solidus temperature and may lead to small degree partial melting. The model of Beyer et al. (2016) shows that the $\mathrm{F} / \mathrm{H}_{2} \mathrm{O}$ ratio in the residual increases with increasing melt 
percentage, which is dependent on the amount of water that is added to the system. Simultaneously, addition of small amounts of water will increase the fluorine partition coefficient between olivine and melt (Fig. 3). Consequently, the addition of small amounts of water to a dry peridotitic system may lead to a significantly stronger increase in the F/ $\mathrm{H}_{2} \mathrm{O}$ ratio of the residual during a small degree partial melting event than predicted by the model of Beyer et al. (2016) and may provide a mechanism that explains the generation of high $\mathrm{F} / \mathrm{H}_{2} \mathrm{O}$ ratios and high fluorine concentrations in the upper mantle without the requirement of multiple partial melting episodes.

However, there are several assumptions in this scenario that need to be tested before it can be verified. We consider in this study only the bulk $\mathrm{H}_{2} \mathrm{O}$ content and not the water activity. Further experiments are required to investigate, if a decrease in water activity (e.g., through addition of $\mathrm{CO}_{2}$ ) affects the fluorine partitioning behavior between olivine and melt. Another assumption that needs to be tested is whether partitioning of water into olivine is affected by the addition of fluorine to the system. If the above-described incorporation mechanism of clumped $\mathrm{OH} / \mathrm{F}$ defects in olivine ("Halogen incorporation mechanism in olivine") proposed by Crépisson et al. (2014) is correct, then it seems likely that $\mathrm{OH}$ partitioning into olivine is affected by fluorine as well, so that fluorine and water affect the partitioning behavior and thus the compatibility of each other. This would not only affect absolute water and fluorine concentrations in melts and residuals after partial melting events but also the respective $\mathrm{F} / \mathrm{H}_{2} \mathrm{O}$ ratios.

Currently, the only conclusion that can be drawn with confidence is that the presence of small amounts of water needs to be considered when estimating the fluorine partition coefficient between olivine and silicate melt at Earth's uppermost mantle conditions and the fluorine concentration in OIB source regions.

\section{Conclusions}

- Results of this study show that there is within uncertainty no effect of water on the chlorine partitioning behavior between olivine and melt at $1280^{\circ} \mathrm{C}, 0.3 \mathrm{GPa}$, and a bulk water content ranging from 0.03(2) to 0.33 (6) $\mathrm{wt} \% \mathrm{H}_{2} \mathrm{O}$. In contrast, fluorine partition coefficients increase linearly within this range with

$$
\begin{aligned}
D_{F}^{\mathrm{o} / \mathrm{melt}}= & 3.6 \pm 0.4 \times 10^{-3} \times X_{\mathrm{H}_{2} \mathrm{O}}(\mathrm{wt} \%) \\
& +6 \pm 0.4 \times 10^{-4} .
\end{aligned}
$$

- The combined incorporation of fluorine and hydrogen into the olivine structure increases the partitioning of fluorine into olivine. This is consistent with the suggested formation of clumped $\mathrm{OH} / \mathrm{F}$ defects in the forsterite structure (Crépisson et al. 2014), which increase the defect stability compared to solely hydrolytic weakening.

- The effect of water on the fluorine and chlorine partitioning behavior between olivine and melt can be neglected for estimates of chlorine in MORB and OIB source regions and fluorine in MORB source regions. In the simplified iron-free $\mathrm{CMAS}+\mathrm{F}-\mathrm{Cl}-\mathrm{Br}-\mathrm{I}-\mathrm{H}_{2} \mathrm{O}$ system, only the effect of temperature on the partitioning behavior needs to be considered as a firstorder controlling factor for the determination of these source region concentrations.

- Considering the effect of water on the fluorine partitioning behavior between olivine and melt indicates that fluorine OIB source region estimates are about $10 \%$ lower than previously expected (Joachim et al. 2015). This implies that the effect of water on the fluorine partitioning behavior between Earth's mantle minerals and silicate melt needs to be considered for a correct estimation of fluorine abundances in OIB source regions.

Acknowledgements Open access funding provided by University of Innsbruck and Medical University of Innsbruck. We especially thank the team of the Ion Microprobe facility at the University of Edinburgh for performing halogen analyses. We are grateful for detailed reviews of three anonymous reviewers, who substantially improved the quality of this paper. This work was performed in the framework of the "NOBLE" (The Origin, Accretion and Differentiation of extreme Volatiles in Terrestrial Planets) research project and funded by the European research Council (ERC) grant no. 267692 under the European Commission Seventh Framework Programme (FP7).

Open Access This article is distributed under the terms of the Creative Commons Attribution 4.0 International License (http:// creativecommons.org/licenses/by/4.0/), which permits unrestricted use, distribution, and reproduction in any medium, provided you give appropriate credit to the original author(s) and the source, provide a link to the Creative Commons license, and indicate if changes were made.

\section{References}

Acosta-Vigil A, London D, Morgan GB VI, Dewers TA (2006) Dissolution of quartz, albite, and orthoclase in $\mathrm{H}_{2} \mathrm{O}$-saturated haplogranitic melt at $800^{\circ} \mathrm{C}$ and $200 \mathrm{MPa}$ : diffusive transport properties of granitic melts at crustal anatectic conditions. J Pet 47:231-254

Berndt J, Liebske C, Holtz F, Freise M, Nowak M, Ziegenbein D, Hurkuck W, Koepke J (2002) A combined rapid-quench and $\mathrm{H}_{2}$-membrane setup for internally heated pressure vessels: description and application for water solubility in basaltic melts. Am Mineral 87:1717-1726

Bernini D (2011) Halogens and Trace Elements in Subduction Zones. Dissertation, University of Bayreuth

Bernini D, Wiedenbeck M, Dolejs D, Keppler H (2013) Partitioning of halogens between mantle minerals and aqueous fluids: 
implications for the fluid flow regime in subduction zones. Contrib Mineral Petrol 165:117-128

Beyer C, Klemme S, Wiedenbeck M, Stracke A, Vollmer C (2012) Fluorine in nominally fluorine-free mantle minerals: experimental partitioning between olivine, orthopyroxene and silicate melts with implications for magmatic processes. Earth Planet Sci Lett 337-338:1-9

Beyer C, Klemme S, Grützner T, Ireland TR, Magee CW, Frost DJ (2016) Fluorine partitioning between eclogite garnet, clinopyroxene, and melt at upper mantle conditions. Chem Geol 437:88-97

Boettcher AL, Mysen BO, Allen JC (1973) Techniques for the control of water fugacity and oxygen fugacity for experimentation in solid-media high-pressure apparatus. J Geophys Res 78:5898-5901

Brodholt JP, Refson K (2000) An ab initio study of hydrogen in forsterite and a possible mechanism for hydrolytic weakening. J Geophys Res 105(B8):18977-18982

Crépisson C, Blanchard M, Bureau H, Sanloup C, Withers AC, Khodja H, Surblé S, Raepsaet C, Béneut K, Leroy K, Giura P, Balan E (2014) Clumped fluoride-hydroxyl defects in forsterite: implications for the upper mantle. Earth Planet Sci Lett 390:287-295

Dalou C, Koga KT, Shimizu N, Boulon J, Devidal JL (2012) Experimental determination of $\mathrm{F}$ and $\mathrm{Cl}$ partitioning between lherzolite and basaltic melt. Contrib Mineral Petrol 163:591-609

Dalou C, Koga KT, Le Voyer M, Shimizu N (2014) Contrasting partitioning behavior of $\mathrm{F}$ and $\mathrm{Cl}$ during hydrous mantle melting: implications for $\mathrm{F} / \mathrm{Cl}$ signature in arc magmas. Prog Earth Planet Sci 1:26. doi:10.1186/s40645-014-0026-1

Danyushevsky LV, Eggins SM, Fallon TJ, Christie DM (2000) $\mathrm{H}_{2} \mathrm{O}$ abundance in depleted to moderately enriched mid-ocean ridge magmas. Part I: incompatible behavior, implications for mantle storage, and origin of regional variations. J Petrol 41:1329-1364

Déruelle B, Dreibus G, Jambon A (1992) Iodine abundances in oceanic basalts: implications for Earth dynamics. Earth Planet Sci Lett 108:217-227

Dixon JE, Clague DA, Wallace P, Poreda R (1997) Volatiles in alkali basalts from the North Arch Volcanic Field, Hawaii: extensive degassing of deep submarine-erupted alkali series lavas. J Petrol 38:911-939

Dixon JE, Leist L, Langmuir C, Schilling JG (2002) Recycled dehydrated lithosphere observed in plume-influenced mid-oceanridge basalt. Nature 420:385-389

Drury MR (1991) Hydration-induced climb dissociation of dislocations in naturally deformed mantle olivine. Phys Chem Miner 18:106-116

Erdmann M, Koepke J (2016) Experimental temperature cycling as a powerful toll to enlarge melt pools and crystals at magma storage conditions. Am Mineral 101:960-969

Green DH, Hibberson WO, Rosenthal A, Kovács I, Yaxley GM, Fallon TJ, Brink F (2014) Experimental study of the influence of water on melting and phase assemblages in the upper mantle. $\mathrm{J}$ Petrol 55:2067-2096

Hauri EH (2002) SIMS analysis of volatiles in silicate glasses, 2: Isotopes and abundances in Hawaiian melt inclusions. Chem Geol 183:115-141

Hauri EH, Gaetani GA, Green TH (2006) Partitioning of water during melting of the Earth's upper mantle at $\mathrm{H}_{2} \mathrm{O}$-undersaturated conditions. Earth Planet Sci Lett 248:715-734

Hermann J, Fitz Gerald J, Malaspina N, Berry AJ, Scambelluri M (2007) OH-bearing planar defects in olivine produced by the breakdown of Ti-rich humite minerals from Dabie Shan (China). Contrib Mineral Petrol 153:417-428

Hirschmann MM (2006) Water, melting, and the deep Earth $\mathrm{H}_{2} \mathrm{O}$ cycle. Annu Rev earth Planet Sci 34:629-653
Hunt JB, Hill GP (1993) Tephra geochemistry: a discussion of some persistent analytical problems. The Holocene 3:271-278

Ito E, Harris DM, Anderson AT (1983) Alteration of oceanic crust and geologic cycling of chlorine and water. Geochim Cosmochim Acta 47:1613-1624

Jambon A, Déruelle B, Dreibus G, Pineau F (1995) Chlorine and bromine abundance in MORB: the contrasting behavior of the MidAtlantic Ridge and East Pacific Rise and implictaions for chlorine geodynamic cycle. Chem Geol 126:101-117

Jamtveit B, Brooker R, Brooks K, Larsen LM, Pedersen T (2001) The water content of olivines from the North Atlantic Volcanic Province. Earth Planet Sci Lett 186:401-415

Joachim B, Gardés E, Velickov B, Abart R, Heinrich W (2012) Experimental growth of diopside + merwinite reaction rims: The effect of water on microstructure development. Am Mineral 97:220-230

Joachim B, Pawley A, Lyon IC, Marquardt K, Henkel T, Clay PL, Ruzié L, Burgess R, Ballentine CJ (2015) Experimental partitioning of $\mathrm{F}$ and $\mathrm{Cl}$ between olivine, orthopyroxene and silicate melt at Earth's mantle conditions. Chem Geol 416:65-78

Johnson L, Burgess R, Turner G, Milledge JH, Harris JW (2000) Noble gas and halogen geochemistry of mantle fluids: comparison of African and Canadian diamonds. Geochim Cosmochim Acta 64:717-732

Kitamura M, Kondoh S, Morimoto N, Miller GH, Rossman GR, Putnis A (1987) Planar OH-bearing defects in mantle olivine. Nature 328:143-145

Kovács I, Green DH, Rosenthal A, Hermann J, O’Neill HSt, Hibberson WO, Udvardi B (2012) An experimental study of water in nominally anhydrous minerals in the upper mantle near watersaturated solidus. J Petrol 53:2067-2093

Kovalenko MA, Naumov V, Girnis A, Dorofeeva V, Yarmolyuk V (2006) Composition and chemical structure of oceanic mantle plumes. Petrology 14:452-476

Kuehn S, Froese D, Pearce N, Foit F (2009) ID3506, a new/old Lipari obsidian standard for characterization of natural glasses and for tephrochronology. AGU fall meeting 2009, V31E-2010 (abstr.)

Le Roux PJ, Shirey SB, Hauri EH, Perfit MR, Bender JF (2006) the effects of variable sources, processes and contaminants on the composition of the northern EPR MORB $\left(8-10^{\circ} \mathrm{N}\right.$ and $\left.12-14^{\circ} \mathrm{N}\right)$ : evidence from volatiles $\left(\mathrm{H}_{2} \mathrm{O}, \mathrm{CO}_{2}, \mathrm{~S}\right)$ and halogens (F, Cl). Earth Planet Sci Lett 251:209-231

Ludwig T, Stalder R (2007) A new method to eliminate the influence of in situ contamination in SIMS analysis of hydrogen. J Anal At Spectrom 22:1415-1419

Matjuschkin V, Brooker RA, Tattich B, Blundy JD, Stamper CC (2015) Control and monitoring of oxygen fugacity in piston cylinder experiments. Contrib Mineral Petrol 169:9. doi:10.1007/ s00410-015-1105-Z

McDonough WF (1990) Constraints on the composition of the continental lithospheric mantle. Earth Planet Sci Lett 101(1):1-18

McDonough WF, Sun SS (1995) The composition of the Earth. Chem Geol 120:223-253

Mercier M, Di Muro A, Métrich N, Giordano D, Belhadj O, Mandeville CW (2010) Spectroscopic analysis (FTIR, Raman) of water in mafic and intermediate glasses and glass inclusions. Geochim Cormochim Acta 74:5641-5656

Michael PJ (1988) The concentration, behaviour and storage of $\mathrm{H}_{2} \mathrm{O}$ in the suboceanic upper mantle: implications for mantle metasomatism. Geochim Cosmochim Acta 52:555-566

Michael PJ (1995) Regionally distinctive sources of depleted MORB: evidence from trace elements and $\mathrm{H}_{2} \mathrm{O}$. Earth Planet Sci Lett 131:301-320 
Michael PJ, Schilling JG (1989) Chlorine in mid-ocean ridge magmas: evidence for assimilation of seawater-influenced components. Geochim Cosmochim Acta 53:3131-3143

Newsom HE (1995) Composition of the solar system, planets, meteorites, and major terrestrial reservois. In: Global Earth Physics, A Handbook of Physical Constants, AGU Reference Shelf, 3rd edn. Elsevier, pp 123-166

Nichols ARL, Carroll MR, Höskuldsson A (2002) Is the Iceland hot spot also wet? Evidence from the water contents of undegassed submarine and subglacial pillow basalts. Eart Planet Sci Lett 202:77-87

O'Leary J, Gaetani GA, Hauri EH (2010) The effect of tetrahedral $\mathrm{Al}^{3+}$ on the partitioning behavior of water between clinopyroxene and silicate melt. Earth Planet Sci Let 297:111-120

Palme H, O’Neill HSC (2014) Cosmochemical estimates of mantle composition. In: Holland HD, Turekian KK (eds) Treat Geochem, vol. 3. Elsevier Ltd, pp 1-39

Patiño Douce AE, Beard JS (1994) $\mathrm{H}_{2} \mathrm{O}$ loss from hydrous melts during fluid-absent piston cylinder experiments. Am Mineral 79:585-588

Pyle DM, Mather TA (2009) Halogens in igneous processes and their fluxes to the atmosphere and oceans from volcanic activity: a review. Chem Geol 263:110-121

Risold AC, Trommsdrof V, Grobéty B (2001) genesis of ilmenite rods and palisades along himite-type defects in olivine from Alpe Arami. Contrib Mineral Petrol 140:619-628

Rosenthal A, Hauri EH, Hirschmann MM (2015) Experimental determination of $\mathrm{C}, \mathrm{F}$, and $\mathrm{H}$ partitioning between mantle minerals and carbonatzed basalt, $\mathrm{CO}_{2} / \mathrm{Ba}$ and $\mathrm{CO}_{2} / \mathrm{Nb}$ systematics of partial melting, and the $\mathrm{CO}_{2}$ contents of basaltic source regions. Earth Planet Sci Lett 412:77-87

Ruzié-Hamilton L, Clay PL, Burgess R, Joachim B, Ballentine CJ, Turner G (2015) Determination of halogen abundances in terrestrial and extraterrestrial samples by the analysis of noble gases produced by neutron irradiation. Chem Geol 437:77-87

Saal AE, Hauri EH, Langmuir CH, Perfit MR (2002) Vapour undersaturation in primitive mid-ocean-ridge basalt and the volatile content of the Earth's upper mantle. Nature 419:451-455

Salters VJM, Stracke A (2004) Composition of the depleted mantle. Geochem Geophys Geosyst 5 (art. No. Q05004)

Schilling JG, Bergeron MB, Evans R (1980) Halogens in the mantle beneath the North-Atlantic. Philos Trans R Soc Lond Ser A-Math Phys Eng Sci 297:147-178

Seaman C, Sherman SB, Garcia MO, Baker MB, Balta B, Stolper E (2004) Volatiles in glasses from the HSDP2 drill core. Geochem Geophys Geosyst 5:Q09G16. doi:10.1029/2003GC000596

Shaw DM (1970) Trace element fractionation during anataxis. Geochim Cosmochim Acta 34:237-243

Shaw AM, Hauri EH, Fischer TP, Hilton DR, Kelley KA (2008) Hydrogen isotopes in Mariana arc melt inclusions: implications for subduction and dehydration and the deep-Earth water cycle. Earth Planet Sci Lett 275:138-145
Simons K, Dixon J, Schilling JG, Kingsley R, Poreda R (2002) Volatiles in basaltic glasses from the Easter-Salas y Gomez seamount chain and Easter microplate: implications for geochemical cycling of volatile elements. Geochem Geophys Geosyst 3:1039. doi: $10.1029 / 2001 \mathrm{GC} 000173$

Smyth JR, Mardel RE, McCormick TC, Monuz JL, Rossman GR (1990) Crystal structure refinement of a F-bearing spessartine garnet. Am Mineral 75:314-318

Smyth JR, Frost DJ, Nestola F, Holl CM, Bromiley G (2006) olivine hydration in the deep upper mantle: effect of temperature and silica activity. Geophys Res Lett 33. doi:10.1029/2006GL026194

Stalder R, Ulmer P (2001) Phase relations of a serpentine composition between 5 and $14 \mathrm{GPa}$ : significance of clinohumite and phase $\mathrm{E}$ as water carriers into the transition zone. Contrib Mineral Petrol 140:670-679

Steinbach V, Yuen DA (1995) The effects of temperature-dependent viscosity on mantle convection with the two major phase transitions. Phys Earth Planet Inter 90:13-36

Stephan T, Lyon IC (2013) Applications of ToF-SIMS in cosmochemistry. In: Vickerman JC, Briggs D (eds), ToF-SIMS: materials analysis by mass spetrometry, 2nd ed. IM publications LLP and SurfaceSpectra Limited

Straub SM, Layne GD (2003) The systematics of chlorine, fluorine, and water in Izu arc front volcanic rocks: implications for volatile recycling in subduction zones. Geochim Cosmochim Acta 67:4179-4203

Truckenbrodt J, Johannes W (1999) $\mathrm{H}_{2} \mathrm{O}$ loss during piston-cylinder experiments. Am Mineral 84:1333-1335

Valley JW, Essene EJ, Peacor DR (1983) Fluorine-bearing garnets in Adirondack calc-silicates. Am Mineral 68:444-448

Visser D (1993) Fluorine-bearing hydrogarnets from Blengsvatn, Bamble sector, south Norway. Mineral Petrol 47:209-218

Wallace PJ, Frey FA, Weis D, Coffin MF (2002) Origin and evolution of the Kerguelen Plateau, Broken Ridge and Kerguelen Archipelago: editorial. J Petrol 43:1105-1108

Wedepohl JD (1995) The composition of the continental crust. Geochim Cosmochim Acta 59:1217-1232

Wirth R, Dobrzhinetskaya LF, Green HW (2001) Electron microscope study of the reaction olivine $+\mathrm{H}_{2} \mathrm{O} \rightarrow$ titanian clinohumite + titanian chondrodite synthesized at $8 \mathrm{GPa}, 1300 \mathrm{~K}$. Am Mineral 86:601-610

Workman RK, Hauri EH, Hart SR, Wang J, Blusztajn J (2006) Volatile and trace elements in basaltic glasses from Samoa: implications for water distribution in the mantle. Earth Planet Sci Lett 241:932-951

Xue X, Kanzaki M, Turner D, Loroch D (2016) Hydrogen incorporation mechanisms in forsterite: ${ }^{1} \mathrm{H}$ NMR measurement and first principles calculation. Goldschmidt Abstracts, 20163503 